УДК 001.8:[658:005.63-047.44]

\author{
Мартиновський В.С. \\ кандидат економічних наук, доцент \\ E-mail: martinV@i.ua \\ Кравець В.Г. \\ магістрант \\ кафедра економіки промисловості \\ Одеська національна академія харчових технологій \\ вул. Канатна, 112, м. Одеса, Україна, 65039 \\ E-mail: nikulyakravets1994@mail.ru
}

\title{
МЕТОДИЧНІ ПІДХОДИ ДО ОЦІНКИ ЕКОНОМІЧНОГО ПОТЕНЦІАЛУ ПІДПРИЄМСТВ
}

\begin{abstract}
У статті розглянуто поняття «економічний потенціал». Проведено аналіз існуючих методичних підходів щодо оцінки економічного потенціалу підприємств. Представлено переваги та обмеження використання різних методів оцінки. Наголошено на необхідності врахування переваг і недоліків певних методичних підходів під час обґрунтування їх вибору для оцінки потенціалу. Запропоновано новий експрес-метод оцінки ефективності використання економічного потенціалу.

ключові слова: економічний потенціал, оцінка, методичні підходи, методи виміру, результативність, коефіцієнт ефективності.
\end{abstract}

Постановка проблеми та її зв'язок з важливими науковими та практичними завданнями. В умовах нестабільності економічного середовища України розвиток підприємств залежить від ефективності формування й використання економічного потенціалу. В цьому аспекті важливим питанням $€$ систематизація, обгрунтування науково-методичних підходів його оцінки й розробка сучасного інструментарію визначення економічного потенціалу.

Дослідження сучасних наукових джерел дозволяє дійти висновку, що на сьогодні не існує єдиного підходу до визначення поняття «економічний потенціал» і його оцінки.

Різні динаміка та спрямованість змін елементів потенціалу спричиняють певні труднощі в управлінні ним. Ці та інші проблеми можна вирішити за допомогою правильно побудованої оціночної системи економічного потенціалу підприємства.

Аналіз останніх публікацій 3 проблеми. Проблемні питання методичних засад і практичної побудови системи оцінки економічного потенціалу підприємства досліджено у наукових працях: Н.А. Абдулаєва, О.Ф. Балацького, Є.В. Лапіна, О.Г. Мендула, І.П. Отенко, С. Попова, А.Н. Тищенка та ін. Запропоновані науковцями підходи до оцінки економічного потенціалу часто суттєво відрізняються, що не сприяє створенню єдиної методики.

Формулювання цілей дослідження. Метою дослідження є аналіз існуючих методичних підходів до оцінки економічного потенціалу підприємства та пропозиції щодо вдосконалення розрахунку ефективності його використання.
Виклад основних результатів та їх обгрунтування. Поняття «економічний потенціал» різними авторами трактується по-різному. Оцінивши всі визначення, можна сказати, що під економічним потенціалом, який є основою господарської діяльності підприємств, слід розуміти сукупні можливості організації, що реалізуються тільки за наявності ресурсів.

Економічні умови, що формуються різним рівнем розвитку ринкових відносин, припускають концентрацію уваги на ефективному управлінні економічним потенціалом підприємства як комплексним показником, що включає:

1) реальні можливості підприємства (реалізовані та нереалізовані) в тій чи іншій сфері економічної діяльності відповідно до його спеціалізації;

2) обсяг ресурсів і резервів підприємства, як залучених, так і не залучених до виробництва;

3) здатності колективу підприємства до ефективного використання ресурсів та резервів 3 метою отримання максимального доходу і прибутку;

4) організаційну структуру підприємства i ефективність обраних форм управління в цілому і на рівні окремих напрямків діяльності або підрозділів;

5) інноваційні можливості підприємства, що визначаються регулярним впровадженням нових товарів, послуг, засобів праці, матеріалів, технологічних процесів, організаційних форм управління і т.д.;

6) інвестиційні можливості підприємства, що характеризуються здатністю нарощувати капітал за рахунок власних джерел i ефективно використовувати позиковий і залучений капітал; 
7) фінансове становище підприємства, що визначається ефективністю управління фінансовими ресурсами: можливість підтримувати необхідний рівень ліквідності і платоспроможності, а також високий рівень фінансової стійкості та ділової активності і т.П.

Накопичений підприємством економічний потенціал може використовуватися ефективно і 3 високою віддачею, а може використовуватися погано 3 низькою віддачею. Іноді фірма 3 невеликим економічним потенціалом (обмеженими ресурсами) досить ефективно його використовує і має високі фінансовоекономічні показники. В іншому випадку підприємство має високий економічний потенціал за всіма складовими і водночас не може вписатися в ринкову кон'юнктуру і має вкрай низьку ефективність своєї діяльності.

Практика показує, що сам потенціал ще не є показником високої результативності роботи підприємства.

Для оцінки економічного потенціалу підприємства необхідно розробляти відповідні методи, що дозволяють визначити не тільки сам потенціал, а й ефективність його використання. Іноді підприємству для отримання більш високих показників фінансовоекономічної діяльності зовсім необов'язково збільшувати свій потенціал, а достатньо підвищити ефективність його використання.

В економіці існує негласне правило, згідно 3 яким зростання ресурсів для розвитку підприємства повинно відбуватися тоді, коли вичерпана можливість підвищення ефективності їх використання, i підприємство має в своєму розпорядженні відповідний інвестиційний капітал.

Процес вивчення діяльності підприємства, 3 точки зору економічного потенціалу та ефективності його використання, необхідний у зв'язку з нагальною потребою ефективного управління цим потенціалом для отримання певних стратегічних результатів.

Методологія оціночної діяльності поєднує три загальновизнаних підходи, кожен із яких характеризується власними методами та прийомами:

- підхід із погляду акумуляції активів - майновий (для підприємства як цілісного майнового комплексу) або витратний (якщо мова йде про оцінку окремих активів);

- порівняльний (ринковий) підхід;

- доходний підхід.

Кожен із підходів характеризується власним методичним інструментарієм. У рамках доходного підходу частіше використовують метод капіталізації та метод дисконтованих грошових потоків; витратний підхід передбачає застосування методів чистих активів та ліквідаційної вартості; при порівняльному підході - методи ринку капіталу, угод та галузевих коефіцієнтів. Такі методи, як ринку капіталу, угод галузевих коефіцієнтів застосовуються за умов ретельного відбору підприємства-аналогу, яке повинно бути того ж типу, що й об'єкт оцінки.

Під час оцінки можуть використовуватись комбінації згаданих підходів переважно тоді, коли об'єкт оцінки складається 3 декількох взаємопов' язаних об'єктів, які оцінюються окремо.

Зважаючи на переваги та недоліки кожного підходу, а також зміст інформації, необхідний для застосування відповідних методів, можна сформулювати загальні умови, коли їх використання дійсно буде виправданим для оцінки наявності потенціалу підприємств торгівлі:

- відносна стабільність і прогнозованість ринкового середовища (товарних ринків, споживчого та фінансового ринків), що забезпечує достовірність і об'єктивність оцінок;

- доступність інформації внутрішнього характеру про реальний стан об'єкта оцінки та його плани щодо характеру розвитку на певних сегментах споживчого ринку;

- більша частина доходів отримується завдяки наявності та експлуатації розвиненої матеріальнотехнічної бази (наприклад, за умов, коли основним напрямом операційної діяльності торговельного підприємства $є$ надання торговельних площ і обладнання в оренду);

- метою оцінки є визначення межі понесених витрат на створення елементів потенцілу під час, наприклад, прийняття рішення про продаж/ліквідацію об'єкта або продовження діяльності на певному сегменті споживчого ринку;

- існування активного ринку купівліпродажу готового торговельного бізнесу, де інформація щодо укладених угод і їх спеціальних умов $є$ відкритою і достовірною;

- наявність і періодичне оновлення статистичних даних щодо значень галузевих мультиплікаторів.

Невідповідність цілей оцінки потенціалу торговельного підприємства визначеним вище умовам забезпечення релевантності ऑii результатів або унеможливлює проведення оцінки взагалі, або робить таку оцінку необ' єктивною.

Економічний потенціал також можна оцінити за допомогою таких методів виміру і оцінки потенціалу підприємства:

1. Ранговий або рейтинговий метод. Потенціал підприємства приймається експертами рівним певному значенню за здалегідь обраною шкалою. Рівень його використання дозволяє ранжирувати підприємства, дозволить оцінити значущість об'єкта господарювання в галузі, у державі.

Для оцінки рівня потенціалу відбирають показники, що дають максимально точну характе- 
ристику господарської діяльності підприємства. Потім кожен показник оцінюється за обраною шкалою.

2. Таксонометричний метод. Здійснюється відбір найбільш значущих для аналізу показників. Створюється матриця критеріальних показників. Критеріальні показники переводяться у безрозмірні величини. Для кожного стовпця цієї матріці виокремлюється максимальне і мінімальне значення показника. При цьому мінімум буде відповідати гіршому 3 економічної точки зору значенню показника, а максимум - найкращому. Слід зазначити, що для показника «Витрати на 1 грошову одиницю вартості продукції» мінімум буде відповідати максимальним витратам, тобто гіршому значенню. Одиничні безрозмірні показники агрегуються для формування показника потенціалу підприємства.

3. Графоаналітичний метод. Потенціал підприємства можна вимірювати у спеціальних одиницях, як позитивних, так і негативних, але при цьому важливим $є$ можливість їх досліджень у динаміці.

У найзагальнішому вигляді графічна модель потенціалу, призначена для проведення діагностики можливостей підприємства, має форму сфери. Така форма репрезентує всі напрямки діяльності підприємства і тим самим розкриває діалектику його потенціалу. Але на практиці важко користуватися сферичною формою для оцінки потенціалу підприємства.

Проаналізував існуючі методики виміру економічного потенціалу можна дійти висновку, що вони не $є$ доцільними, так як потребують багато часу на розрахунки і не завжди вистачає необхідних даних.

Економічний потенціал організації характеризується не тільки наявністю ресурсів, а й ефективністю їх використання, оскільки наявність однакових потенційних можливостей не гарантує отримання однакового економічного потенціалу.

Можна вважати, що для оцінки ефективності використання економічного потенціалу достатньо таких показників, як рентабельність та витрати на 1 гривню реалізованої продукції.

Пропонуємо новий метод оцінки - експресаналіз за допомогою коефіцієнту ефективності використання економічного потенціалу.

Метою такого аналізу $\epsilon$ наочна i проста оцінка стану та динаміки розвитку суб'єкта господарювання.

Ефективність як показник результативності припускає порівняння витрат з результатом.
Коефіцієнт ефективності використання економічного потенціалу призначений для того, щоб показати, наскільки успішно керівництво підприємства використовувало економічний потенціал компанії.

Коефіцієнт ефективності використання економічного потенціалу пропонуємо розраховувати за формулою:

$$
K_{\text {eвеп }}=R_{\text {pп }} \times \mathrm{B}_{\text {на } 1 \text { грн рл }}
$$

де Rpп - рентабельність реалізованої продукціï;

Вна 1 грн рп - витрати на одну гривню реалізованої продукції

або

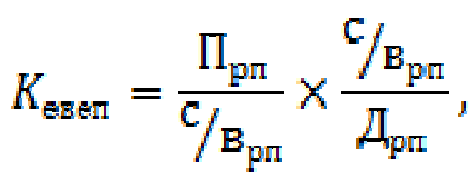

де Прп - прибуток від реалізації продукції;

С/Врп - собівартість реалізованої продук-

ціï;

Дрп - чистий дохід від реалізованої продукції.

Для розрахунку необхідно брати дані за 2 роки і більше. Для наочної оцінки зміни ефективності використання економічного потенціалу можна побудувати графік.

Висновки та перспективи подальших досліджень. В результаті дослідження встановлено, що в існуючих наукових дослідженнях відсутній єдиний підхід до оцінки економічного потенціалу підприємства та його ефективності. Виявлено недоцільність більшості методів, так як вони займають багато часу на розрахунки і не завжди вистачає необхідних даних для їх використання. Запропоновано новий метод експрес-аналіз за допомогою коефіцієнту ефективності використання економічного потенціалу і обгрунтовано доцільність його використання.

Для оцінки економічного потенціалу підприємства необхідно розробляти відповідні методи, що дозволяють визначити не тільки сам потенціал, а й ефективність його використання. Іноді підприємству для отримання більш високих показників фінансово-економічної діяльності зовсім необов'язково збільшувати свій потенціал, а достатньо підвищити ефективність його використання. 


\title{
Література
}

1. Балацкий О. Ф. Экономический потенциал административных и производственных систем: монография / О. Ф. Балацкий, Е. В. Лапин, В. Л. Акуленко ; под общ. ред. О. Ф. Балацкого. - Суммы : Университетская книга, 2006. - 972 с.

2. Есипов В. Оценка бизнеса / В. Есипов, Г. Маховикова, В. Терехова - СПб. : Питер, 2001. - 416 с.

3. Ковалев А. И. Анализ хозяйственного состояния предприятия / А. И. Ковалев, В. П. Привалов. - М. : ЦЭиМ, 1999. - 216 с.

4. Коласс Б. Управление финансовой деятельностью предприятия: [пер. с франц] / Б. Коласс. - М. : Финансы, ЮНИТИ, 1997. - 186 с.

5. Лапін Є. В. Економічний потенціал підприємств промисловості: формування, оцінка, управління: автореф. дис.... д-р екон. наук: 08.07.01 / Лапін Євген Васильович. - Х. : ХНСУ, 2006. - 40 с.

6. Отенко И. П. Методологические основы управления потенціалом предприятия : монография / И. П. Отенко. - Х. : ХНЭУ, 2004. - 215 с.

7. Отенко И. П. Стратегическое управление потенциалом предприятия: монография / И. П. Отенко. - Х. : ХНЭУ, 2006. - 254 c. 2000. $-352 \mathrm{c}$

8. Оценка стоимости предприятия (бизнеса) : учеб. пособие / под ред. Н. А. Абдуллаева - М. : ЭКМОС,

9. Попов Е. Рыночный потенциал предприятия : учебник / Е. Попов. - М. : Экономика, 2002. - 628 с.

10. Федонін О. С. Потенціал підприємства: формування та оцінка : навч.-метод. посібник для самост. вивч. дисц. // О. С. Федонін, І. М. Рєпіна, О. І. Олексик. - К. : КНЕУ, 2005. - 261 с.

Стаття надійшла 09.06.2015

\author{
Мартыновский В.С. \\ кандидат экономических наук, доцент \\ E-mail: martinV@i.ua \\ Кравец В.Г. \\ магистрант \\ кафредра экономики промышленности \\ Одесская национальная академия пищевых технологий \\ ул. Канатная, 112, г. Одесса, Украина, 65039 \\ E-mail: nikulyakravets1994@mail.ru
}

\section{МЕТОДИЧЕСКИЕ ПОДХОДЫ К ОЦЕНКЕ ЭКОНОМИЧЕСКОГО ПОТЕНЦИАЛА ПРЕДПРИЯТИЙ}

В статье рассмотрено понятие «экономический потенциал». Определено, что предприятию для получения более высоких показателей финансово-экономической деятельности иногда совсем необязательно увеличивать свой потенциал, а достаточно повысить эффективность его использования. Проведен анализ существующих методических подходов к оценке экономического потенциала предприятий, таких как: подход с точки зрения аккумуляции активов - имущественный (для предприятия как целостного имущественного комплекса) или затратный (если речь идет об оценке отдельных активов), сравнительный (рыночный) и доходный подходы; ранговый, таксонометрический и графоаналитический методы. Приведена краткая характеристика этих методических подходов. Представлены преимущества и ограничения использования различных методов оценки. Отмечена необходимость учета преимуществ и недостатков определенных методических подходов при обосновании их выбора для оценки потенциала. Предложен новый экспресс-метод оценки эффективности использования экономического потенциала и способы расчета соответствующего коэффициента. Обоснована целесообразность нового метода.

Ключевые слова: экономический потенциал, оценка, методические подходы, методы измерения, результативность, коэффициент эффективности. 


\author{
Martynovsky V.S. \\ Ph.D. in Economics, Associate Professor \\ E-mail: martinV@i.ua \\ Kravets V.G. \\ undergraduate \\ Department of Industrial Economics \\ Odessa National Academy of Food Technologies \\ Kanatna str., 112, Odessa, Ukraine, 65039 \\ E-mail: nikulyakravets1994@mail.ru
}

\title{
METHODOLOGICAL APPROACHES TO ASSESSING THE ECONOMIC POTENTIAL OF THE ENTERPRISES
}

The article discusses the concept of "economic potential". It is determined that the company for higher rates of financial-economic activity sometimes does not necessarily need to increase their potential, but rather to increase the efficiency of its use. It was done the analysis of existing different methodological approaches to estimate the economic potential of companies, such as approach in terms of accumulation of assets - property (for the enterprise as an integral property complex) or expense (in the case of assessment of individual assets), comparative (marketing) and income approach; rank, Graph analytical and taxonometric methods. It is spoken in detail of the above brief description of methodological approaches. It is given advantages and disadvantages of using different valuation techniques. It is mentioned the necessity of consideration of the advantages and disadvantages of using certain methodological approaches during the rationale for their selection for the evaluation of potential. A new rapid method for assessing the efficiency of economic potential and how to calculate the appropriate ratio is proposed. It is given the expediency of the new method.

Keywords: economic potential, evaluation, methodological approaches, methods of measurable, rhenium, effectiveness, efficiency factor.

\section{References}

1. Balatskij O. F. (2006). Ekonomicheskij potentsial administrativnyh i proizvodstvennyh sistem: monografija. O. F. Balatskij, E. V. Lapin, V. L. Akulenko ; pod obsch. red. O. F. Balatskogo. Summy : Universitetskaja kniga, 972.

2. Esipov V., Mahovikova G., Terehova V. (2001). Otsenka biznesa, SPb.: Piter, 416.

3. Kovalev A. I. Privalov V. P. (1999). Analiz hozjajstvennogo sostojanija predprijatija. M.: Ts`EiM, 216.

4. Kolass B. (1997). Upravlenie finansovoj dejatel'nost'ju predprijatija: [per. s frants]. M. : Finansy, JuNITI, 186

5. Lapin C. V. (2006). Ekonomichnij potentsial pidpriemstv promislovosti: formuvannja, otsinka, upravlinnja: avtoref. dis.... d-r ekon. nauk: 08.07.01. H. : HNEU, 40.

6. Otenko I. P. (2004). Metodologicheskie osnovy upravlenija potentsialom predprijatija: monografija. H.: HN'EU, 215.

7. Otenko I. P. (2006). Srategicheskoe upravlenie potentsialom predprijatija: monografija / I. P. Otenko. - H. : HN'EU, 254.

8. Otsenka stoimosti predprijatija (biznesa): ucheb. posobie / pod red. N. A. Abdullaeva (2000). EKMOS, 352.

9. Popov E. (2002). Rynochnyj potentsial predprijatija: uchebnik. M. : Ekonomika, 628 .

10. Fedonin O. S., Repina I. M., Oleksik O. I. (2005). Potentsial pidpriemstva: formuvannja ta otsinka: navch.metod. posibnik dlja sam ost. vivch. dists. K.: KNEU, 261. 